\title{
UN CIRUJANO MILITAR PARA LA PROVINCIA DE ChiHuahua. El CataláN AnTONio ComaduráN ROVIRA (I747-I 8 I 6)
}

MARTÍN CLAVÉ ALMEIDA

SAMUEL RICO MEDINA

\section{RESUMEN}

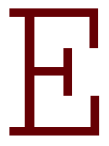

1 proyecto de reformas borbónicas tuvo para las provincias del vasto norte de la Nueva España repercusiones trascendentales, entre ellas la formación de un ejército regular con el propósito de lograr la pacificación de los diversos grupos indígenas en pie de guerra, aumentando y reforzando el número de presidios. La regularización de un ejército bien atendido requería de hospitales dotados de médicos profesionales. Consideramos que la historia de vida de Antonio Comadurán, quien fue el primer médico de los Reales Ejércitos, como aparece en varios documentos, en las Provincias Internas de Occidente, nos aporta una visión esclarecedora de la puesta en práctica de esta nueva estrategia imperial.

Palabras clave: Provincias Internas, Chihuahua, Arizpe, Reformas borbónicas, Reales ejércitos, presidios, indios apaches, hospitales militares. 


\begin{abstract}
The Bourbon Reforms project had far-reaching repercussions for the provinces of the vast north of New Spain, among them the formation of a regular Army with the purpose of achieving the pacification of the various indigenous groups in war, increasing and reinforcing the number of presidios. The regularization of a wellattended army required hospitals staffed by professional doctors. We consider that the life story of Antonio Comadurán, who was the first doctor of the royal army in the Western Provinces, gives us an insight of the implementation of this new imperial strategy.

Key words: Internal provinces, Chihuahua, Arizpe, Bourbonic reforms, Royal army, Presidios, Apache Indians, Military hospitals.
\end{abstract}

\title{
INTRODUCCIÓN
}

El enfoque de estudio a través de una biografía favorece la tarea de reescribir la historia. Vale la pena intentarlo sobre una figura hasta ahora casi desconocida, que sobresalió en muchos sentidos. Un cirujano barcelonés, quien, como funcionario virreinal de los reales ejércitos, destacó durante treinta años como colono y fundador de una familia en Chihuahua y en Arizpe, Sonora, dos ciudades estratégicas para la puesta en práctica de las reformas borbónicas en las Provincias Internas de la Nueva España, a través de las Comandancias generales.

En este ensayo destacaremos el rostro humano de la historia de instituciones administrativas, en este caso la función y estructura de los hospitales reales en provincias internas en la época de los Borbones, al mismo tiempo la historia social de los médicos, que entonces estaban sujetos a una corporación colegiada, para lo que habremos de partir de una historia de vida como la de Antonio Comadurán, durante su estancia en las Provincias Internas (1786-1816), un cirujano catalán, portador de la medicina "protomoderna" en un entorno donde prevalece la medicina tradicional basada en la herbolaria y en tradiciones curativas indígenas. 
La biografía de un médico peninsular depende de su tiempo y de sus circunstancias, así como del espacio y sus lugares, es por ello que habremos de tomar en cuenta el contexto cultural: El saber médico de su tiempo dominado por el Siglo de las Luces, los reglamentos borbónicos de las milicias, la guerra contra los indios indomables, las paces, las treguas y por ende la vida de los soldados del presidio.

Cabe destacar que este ensayo es un primer avance de una investigación más ambiciosa que pretendemos proseguir en archivos españoles. Tenemos evidencias de la vida del genearca de la familia en México, Miguel Antonio Comadurán Rovira, ${ }^{1}$ y la huella de sus pasos en las Provincias Internas, a partir de su nombramiento en 1786 como cirujano de los reales ejércitos en Chihuahua, donde vivió su primera etapa de nueve años hasta 1795, cuando fue nombrado cirujano de Arizpe. En esta ciudad trabajó una segunda etapa hasta el año de 1806, cuando solicitó su retiro. De esta forma regresó a la ciudad de Chihuahua los últimos diez años de su vida. Poco sabemos de él desde su nacimiento en 1747 hasta su llegada a la Nueva España, que pudo ser tiempo antes de su nombramiento. Sus antecedentes familiares, sus años de estudio en Barcelona y el servicio prestado a la corona es lo que habremos de estudiar en los archivos correspondientes de España.

1 Hasta donde sabemos hay tres autores que se ocupan de la familia Comadurán, el primero es Encarnación Brondo Whitt en Los patriarcas del Papigochi, escrito en 1940 y publicado en 1952 (p. 65), él menciona como genearca a José Buenaventura Comadurán Antillón y da los datos correctos de sus padres y que es nieto de nuestro José Antonio Comadurán Rovira. El segundo es James E. Officer, en Hispanic Arizona, 1536-1856 (Appendix C), quien comienza también con José Antonio Comadurán Rovira, pero equivoca el apellido materno anotándolo como Robina e ignorando que nuestro personaje tuvo descendencia no solo en Sonora y luego Arizona, sino también en Chihuahua. El tercero es Leopoldo Amaya González en Patriarcas del papigochi... La descendencia (p. 251), quien parte de (José) Antonio Comadurán, dándole erróneamente como segundo apellido Rovirosa, mencionando como único hijo a Buenaventura y asegurando -sin dar argumentos probatorios- que el apellido Comadurán fuera originariamente Comaduras, y que la familia lo cambió al llegar a América. 


\section{EL ESPACIO}

Según el concepto de geohistoria, planteada por Fernand Braudel, las relaciones sociales se desenvuelven en un espacio específico, de tal modo que en lo que en la actualidad es nuestro territorio nacional, se desarrollaron tres maneras diferentes de reaccionar al proceso histórico conocido como las reformas borbónicas y, por lo tanto, tres trayectorias genéricas, de acuerdo con Carlos Aguirre Rojas: 1) el México árido septentrional, un norte criollo, que nos ocupa. 2) el México templado del altiplano central con alto porcentaje de población mestiza. Fue precisamente aquí en el Bajío, donde prendió la llama de la independencia, y 3) el México tropical, sureste, zona con alta densidad indígena que tuvo al igual que el norte, escasa participación en el movimiento insurgente (2005: pp. 3, 7).

Edmundo O' Gorman señala que en la Real Cedula de 22 de agosto de 1776 dice el rey: que en atención a los grandes encargos, cuidados y obligaciones que tiene mi virrey de México y a la considerable extensión de las vastas provincias que comprende aquel imperio de la Nueva España se trató y propuso desde al año de 1752, a erigir la comandancia y capitanía general de las mencionadas provincias, por no ser fácil aplicar desde la metrópoli de México, las providencias eficaces y oportunas que exigen la suma importancia de ellas: con estos motivos y otros muy urgentes que tuve en consideración, representados por el virrey marques de Croix y el visitador José de Gálvez en 1768, decido resolver en julio de 1769 establecer la comandancia que abarque Sonora, Sinaloa, Californias, Nueva Vizcaya, Tejas y Nuevo México (2007: pp. 16-17).

Nuestra área de estudio abarca un "circuito" que va desde la ciudad de Chihuahua a la ciudad de Arizpe, Sonora, la cual se definió a raíz de las reformas borbónicas implementadas a partir de 1777 y hasta la culminación del proceso independentista en 1821. Se ubica en la vertiente del Pacífico (parte de Sonora), norte central (Chihuahua). Ambas cuentan con suelos ricos en minerales, 
bosques de coníferas y encinos en la sierra entre Sinaloa, Sonora y Chihuahua, así como abundantes pastizales y matorrales (Ceballos Ramírez, 2009: p. 31). ${ }^{2}$

El vasto norte se constituyó en una enorme área cultural compuesta de regiones desarticuladas entre sí, estuvo preñado de procesos sociales que se desarrollaron de una manera singular durante el virreinato y buena parte del siglo XIX. El legado colonial en esta gran porción del territorio nacional fue en la prolongada guerra contra nómadas belicosos. La conquista del Septentrión, la última conquista del imperio español, resultó un proceso inacabado, los nacientes estados republicanos tuvieron que lidiar con la azarosa lucha contra los indios en pie de guerra, quienes se mostraron insumisos a la evangelización desplegada por las misiones y las campañas inconstantes de las tropas presidiales, la lejanía de centros políticos administrativos y económicos, Guadalajara, Durango, Ciudad de México, la vecindad de un territorio al norte, reclamado por la corona, pero no poseído ni domeñado, la conformación geográfica, en fin, todo ello favorecía un escenario de aislamiento, creaba una imagen de discrecionalidad en el cumplimiento de disposiciones oficiales (Almada Bay, 1989: p. 287).

Para hacer un análisis a escala, propuesto por la microhistoria italiana de Giovanni Levi (1993: pp. 122-124) y Carlo Ginzburg (2002: p. 16) hay que tomar en consideración el estudio de dos casos, es decir, de dos regiones que tienen ciertas similitudes, nos referimos a los otrora asentamientos importantes de la Provincias Internas de Occidente: Arizpe, Sonora y Chihuahua; Chihuahua, la joya de la Nueva Vizcaya, las cuales volverán a destacar durante la Revolución Mexicana.

2 En la escala de observación, es necesario ir al contexto histórico en su delimitación regional. Para Eric van Young la región es un sistema interno, cuyos componentes actúan más entre sí que con sistemas externos, aunque a veces estos la delimiten. Afirma van Young (1991: p. 101) que la cualidad de ser de una región radica en el cambio social que ocurre en un espacio definido a lo largo del tiempo. 


\section{LAS REFORMAS BORBÓNICAS}

Ignacio Almada describe puntualmente el proceso de las Reformas a través de las Instrucciones que Bernardo Conde de Gálvez dirige en 1786 al General de las Provincias Internas Jacobo Ugarte y Loyola. Le señala que a pesar de tantos esfuerzos para atraer con "maña y dulzura" a los indígenas, el estado de las provincias se muestra decadente, que el aumento de la fuerza, en otras palabras, la militarización de la frontera, había multiplicado las hostilidades, por lo que sería mejor provocar que los gentiles se destruyan a sí mismos, es decir, "dividir para vencer" (Almada Bay, 1989: p. 276).

Espera el conde que las paces negociadas, mediante las cortas dádivas que los españoles extienden a los indígenas, los cambalaches o permutas de los productos de los aborígenes, pero sobre todo en la extensión del "comercio que enlaza y estrecha las voluntades de los hombres... administrándoles la paz en cualquier parte que la soliciten”. Indisponerlos entre ellos, suministrarles bebidas para crearles una nueva necesidad que los haga dependientes de los españoles, difusión a las armas de fuego, para que sustituyan arco y flecha, armas muy ventajosas para los indios (p. 277). Se deseaba limitar las acciones militares a la simple defensa y atraer a los indios a la "civilización" a través de regalos y aumentando el comercio para hacerlos dependientes del mercado de artículos españoles, sobre todo de alcohol y pólvora (Velasco Ávila, 2015: p. 188).

Ignacio del Río señala que es significativo el periodo de 1768 a 1787 para la historia de la provincia, inicialmente Arizpe, por las siguientes razones: el establecimiento de una temprana y aislada intendencia de Real Hacienda (1770-1787), el influjo personal de José de Gálvez, primero como visitador general de Real Hacienda de la Nueva España y más tarde como Secretario de Indias hasta su muerte en 1787, y la permanencia en el trono de Carlos III, el borbón más radical, quien falleció en 1788. Las reformas fueron aquí la expresión regional de un proceso decisivo (2012: p. 16). Desde 1779, la comandancia general se fijó en el pueblo, luego ciudad de Arizpe (1989: p. 278). En 1772, el rey aprobó el ordenamiento militar, reglamentó y dio instrucción para los presidios que 
se han de formar en la línea de frontera de la Nueva España. Al entrar en vigor este reglamento, las tropas presidiales quedaron organizadas como fuerzas regulares del ejército español (2012, pp. 155-156). De los seis presidios existentes entonces en la gobernación de Sonora y Sinaloa, localizados en Fronteras, Terrenate, Tubac, Altar, Horcasitas y Buenavista, quedó determinado que se reubicaran los cuatro primeros y se extinguieran los dos últimos. A la postre se reubicaron tres presidios, Fronteras en el valle de San Bernardino, el de Terrenate en Santa Cruz y el de Horcasitas en Buenavista, porque se estimaron necesarios para defensa de dos zonas, una seri y pima y otra cahíta. La real caja de Álamos empezó a funcionar el $1^{\circ}$ de julio de 1769. La pagaduría de Arizpe quedó establecida el 10 de marzo de 1780 (pp. 156 y 181).

Para mejorar la administración de las extensas regiones norteñas, surgía la Comandancia militar de las Provincias Internas (1776), cuyo comandante general llegó a tener funciones de gobierno y justicia en forma independiente del virrey, lo que generó serios conflictos entre autoridades virreinales, comandantes, colonos y misioneros. Esto y los continuos ataques de los nómadas, marcaron la tónica de las tierras de frontera. Las reformas más importantes se dieron entre 1759 y 1788 bajo el monarca Carlos III y con la ayuda del visitador José de Gálvez. Junto a la división administrativa se introdujo una nueva institución: el ejército. A partir de 1764 se formaron regimientos y tropas, el ejército se convirtió paradójicamente, en una nueva vía de ascenso para criollos y mestizos (Rubial García, 2012: pp. 186-190).

La conformación de un poderoso ayuntamiento, la comandancia militar, la reglamentación de las milicias y la colonización multiétnica contribuyeron a la tendencia autonomista (p. 1037). Esto explica la inclinación de las élites a la contrainsurgencia, que permanecieron leales a la Corona. La paz se logró con muchos esfuerzos por parte de una sociedad deseosa de ella, preocupada por la frontera desde que los angloamericanos se hicieron de Luisana en 1804. Con la militarización los criollos lograron un mayor estatus social. La milicia y el régimen de las colonias militares 
contribuyeron a la conformación de una sociedad menor jerarquizada, enfrentada a un enemigo común: el apache (pp. 1041-1042).

\section{INDIOS DE PAZ E INDIOS DE GUERRA}

Es necesario tomar en consideración la peculiaridad de los indígenas del Norte de la Nueva España en el periodo de las reformas borbónicas, mediante las cuales la Corona intentó resolver las erráticas relaciones con los belicosos e indómitos grupos indígenas. El objetivo central era asegurar las antiguas fronteras y establecer otras más al norte en una época en que potencias, sobre todo las monarquías de Francia e Inglaterra ambicionaban y hacían acto de presencia en los territorios atractivos y poco resguardados del imperio de España. Los constantes vaivenes de la "nueva política" inducirían relaciones a veces de contradicción y enfrentamiento y a veces de negociación o tregua. De hecho, los emisarios de las amenazantes potencias dotaban de armas a los diferentes grupos de indígenas en pie de guerra (Carolina Ibarra, 2010, pp. 15-16).

Cuauhtémoc Velasco señala que al respecto de esta temática prevalece una visión muy sesgada sobre el "intercambio cultural que se dio entre los pueblos nómadas con los enclaves novohispanos". Se sabe poco de los belicosos apaches y comanches. Apunta que el ministro de hacienda, Joseph de Campillo, propuso en 1789 establecer fuertes que al mismo tiempo fueran almacenes de mercancías para establecer comercio con los indios independientes y que los gobernadores e intendentes se ganaran la voluntad de los caciques a través de regalos, es decir, atraer hacia el comercio los indios bravos. Esta tendencia implicaba combinar fuerza y negociación y utilizar las rivalidades entre grupos indios (Velasco Ávila, 2015: pp. 20-22).

Debemos comenzar por destacar la singularidad del norte, donde el nombre de indígena adquiere otras connotaciones. En los expedientes del ramo de Provincias Internas abundan los calificativos de los grupos nómadas del norte, tales como indios mecos, indios enemigos, indios bravos, indios bárbaros (Escobar y Rojas, 
1992: p. 25). Para los apaches la guerra era un acto religioso y ello explica su actitud de combate (Velasco Ávila, 2015: p. 83).

Según Miguel León-Portilla en el gran norte, que abarcaba desde Durango hasta los territorios de los cuales se adueñaron los Estados Unidos en 1848, una extensión cercana a tres millones de kilómetros cuadrados, tanto la población indígena como la noindígena eran escasas. Calcula que la población total no rebasaba en mucho las 400 mil personas y que posiblemente "algo más de la mitad eran indígenas" (2011: p. 24).

El célebre antropólogo Gonzalo Aguirre Beltrán, señalaba en 1971, que en el norte del país habitaban bandas de cazadores, recolectores, pescadores y agricultores primitivos que fueron sistemáticamente exterminados al resistir su conversión en "reservorios de mano de obra” para el trabajo en las minas, las haciendas y las misiones de los colonizadores. Alcanzada la independencia, las bandas que lograron sobrevivir, fueron motivo de persecución constante hasta su extinción. Dijo que de estos indios llamados "bravos" no quedaban para ese entonces sino unos cuantos remanentes en el refugio de las sierras de Baja California, Chihuahua o el desierto de Sonora. Concluyó puntualizando que el número de "bandas" era infinito y, por lo tanto, el de lenguas que hablaban (pp. 13-14).

Señala Antonio García de León que:

En todo este universo se distinguían los indómitos apaches: cazadores y ladrones de caballos, excelentes jinetes y grandes guerreros que en las carneadas del bisonte...hacían caer a las bestias una a una para despellejarlas y curtir sus cueros... Y aunque habían adoptado las armas de fuego, que intercambiaban con los forasteros, seguían siendo los mejores flecheros de la América septentrional y sus manos expertas imprimían a las saetas de mimbre y carrizo una fuerza mortal que aterrorizaba a sus enemigos, pues eran capaces de atravesar con ellas un bisonte, así como las cueras curtidas y las adargas que los colonos usaban como inútiles cotas de defensa (2017: pp. 15-16). 
En su Memoria para la historia de la provincia de Texas, publicada en Madrid en 1779, fray Juan Agustín Morfi describe las diversas "naciones" que habitan dicha provincia, destacando el grado de belicosidad, su alianza establecida entre las "bandas" y su pacificación. Así distingue entre indios de paz e indios de guerra, que huyen de las misiones y del trato con los colonos españoles. Señala sus costumbres: la mayoría de los indios de guerra eran dados a los "mitotes", al robo, especialmente de ganado, a la ociosidad y algunos a la antropofagia. Muchos de los grupos de los que da cuenta habían venido a menos, algunos sobrevivían reunidos en pequeñas tribus, muchas de ellas descendientes de los indios texas. A los descendientes de estos últimos los considera laboriosos en el cultivo del maíz y de huertos frutales, leales de los españoles a quienes han asistido en la guerra contra sus enemigos como excelentes flechadores y curtidores de pieles (2003: pp. 48-49). ${ }^{3}$

\section{LOS PRESIDIOS PROVINCIALES}

Los presidios militares, al igual que los de la alta California, no eran esos lugares de aburrimiento que aparecen en las distintas series de "El Zorro"; por el contrario, en los presidios militares del gran norte septentrional sucedían acciones crueles: "torturas, violaciones, desollamiento de cabelleras y decapitaciones formaban parte de este juego de guerra, infundiendo terror en ambos bandos" (García de León, 2017: p. 57).

La descripción que hace fray Agustín Morfi del presidio San Juan Bautista de Río Grande del Norte, a fines de 1777, vale para la mayoría de los presidios de las Provincias Internas: el capitán de esta compañía es al mismo tiempo justicia mayor en lo civil y lo criminal del presidio y su jurisdicción. Incluidas las misiones. Cabe señalar que el arsenal de armamento del presidio se reducía a 68 escopetas, 23 fusiles, 29 pistolas, 17 trabucos, 29 espadas, 33

3 Las "naciones" detalladas son los carancagues, atacapas, horcoquizas, xaranames, cocos, muleyes, ayxs, navedachos, nacogdochitos, ahijiyos, nacogodches, asinais, nasonis, cadodachos, tancagues, quitseis, tuacana, ahechago, obaes, comanches y ozages (pp. 37-52). 
lanzas, 20 cueras, 59 adargas, 113 sillas, 107 frenos, 97 cojinillos, 91 espuelas y 129 hombres de arco y flecha. Lo que resulta sorprendente es que la defensa descansa en los indios flecheros aliados (2003: pp. 16-17).

A Teodoro de Croix le aterraba la idea de defender una frontera de $2880 \mathrm{~km}$ con menos de 2 mil soldados. Su innovación más importante fue la creación en 1778 de una tropa ligera y que no usaba la rígida chaqueta de piel de 8 kilos, la lanza de más de un kilo, el escudo de kilo y medio, ni alguno de los demás atavíos que exigía el reglamento, menos recargados que los soldados de cuera, se desplazaban con mayor rapidez, se requería de menos caballos y podrían pelear a pie, necesitaban menos provisiones y aumenta el número de soldados en un 50 \% de 1900 a 2840 según Moorhead (Weber, 2000: p. 323).

A partir del 2 de septiembre de 1801 se publicó por bando en villa de San Jerónimo, la Ciudad de Chihuahua y en los presidios de la línea de frontera, la cédula real del 17 de octubre de 1800 donde se declaran exentos de pagar diezmos y primicias a todos los habitantes de los puestos militares de estas provincias y de las estancias que dependan de ellas. La orden de bando para ser publicado en los presidios está firmada en San Jerónimo por Antonio García de Tejeda, Juan Trujillo y José Cano (AGN, vol. 57, 1790).

Charles Gibson, presenta un cuadro sugerente sobre las características de los presidios y la vida de los vaqueros en tierras de frontera, sobre todo de Nuevo México y Texas, asediada por indios nómadas. El autor señala que las tierras fronterizas, marcan los linderos o límites (borderlands) de territorios en disputa. Los presidios, característicos de las tierras fronterizas más al interior, estaban destinados a ser puestos de avanzada en la móvil frontera, como protección contra los ataques de los indios merodeadores (1977: pp. 299 y 312).

Cuando terminó la guerra con los chichimecas, y debido a las expansiones más deliberadas de los siglos XVII y XVIII, el presidio se convirtió en una genuina fortaleza fronteriza. Los presidios del norte de México y de los límites de los Estados Unidos de Norte-

4 Los soldados y paisanos que residan en presidios quedan exentos de pagar diezmos y primicias. 
américa tenían un personal de unos 60 soldados españoles, que vivían dentro o cerca de las pequeñas fortificaciones de adobe, rodeados de sus familias, los criados indios y una miscelánea de individuos que se habían quedado a vivir allí. Los soldados estaban equipados con caballos y armas de fuego (fusileros), con los cuales salían en expediciones punitivas contra los indios aún no pacificados. Los españoles iban acompañados a menudo por soldados indios en sus correrías contra otros indios. Además de su primaria función defensiva, los soldados eran empleados como correos, pagadores, escoltas militares, policías y guardas. Uno de los principales problemas administrativos fue aprovisionar a los improductivos presidios de la frontera. Los rebaños pastaban a voluntad en aquellas zonas no colonizadas y sin vallados, invadiendo a veces los poblados fronterizos como bandas salvajes. ${ }^{5}$ Las faenas de vaqueros, la equitación, los extensos pastos abiertos, el rodeo, los atavíos de plata, y la "psicología del charro" se convirtieron pronto en rasgos permanentes de la zona. El rodeo fue la solución mexicana al problema de los animales sin herrar que andaban sueltos (ganado mesteño). El rodeo mexicano tiene analogías en otras partes del mundo, pero se desarrolló de modo independiente y en todo caso, adquirió modalidades especiales. El rodeo originalmente, que no era la exhibición pública de la destreza en echar el lazo y cabalgar que ahora conocemos, era literalmente un rodeo, con vaqueros a caballo dispuestos en un círculo lo bastante grande para rodear a los animales y encerrarlos en un área cada vez más pequeña. En el centro se identificaban los hierros de las

5 Una de las ordenanzas más tempranas para las Provincias Internas de Occidente, publicada en 1729, fue resultado del diario de visita escrito por el Inspector Pedro de Rivera. Dicha ordenanza para el buen gobierno nos permite atisbar la vida cotidiana de los presidios: "Debe haber un cuerpo de guardia para castigar a los indisciplinados. Debe rezarse a coro el rosario a Nuestra Señora con mayor devoción. Debe pasarse revista. Que los soldados usen capote solo en tiempos de lluvias para resguardo de armas y cueras. Estando de guardia no se despojarán de la cuera y armas, so pena de no pagarles sueldo. Prohibido vender caballos, juramentos, blasfemias y falsos testimonios. Prestar escolta para custodiar al santísimo sacramento. Que los comandantes no se apoderen de los sueldos de las plazas vacías. No deben los oficiales precios subidos de las mercancías. Se mudará la guardia cada quince días. Ningún oficial montará a caballo sin llevar cuera. Finalmente, se enumeran precios de efectos necesarios para los presidiales" (Rivera, 1946: pp. 215-231). 
distintas ganaderías y los animales que no estuvieran marcados se distribuían entre los propietarios. El rodeo dejó un legado español permanente en las zonas ganaderas de los Estados Unidos (Gibson, 1977: pp. 313-314).

Las Provincias Internas de Sonora y Chihuahua, que eran la columna vertebral en la frontera norte, por permanecer remotas y aisladas, fueron virtualmente independientes en lo político y autosuficientes en lo económico, los colonos militares, gente que más contribuye a hacer de la frontera un lugar habitable. A mediados del siglo XVIII la corona española había fundado colonias militares a lo largo de la frontera norte para ahuyentar a las bandas de apaches y demás nómadas que merodeaban por la región. El método utilizado era siempre el mismo: se dotaba de tierra en esta zona a cualquiera que estuviera dispuesto a tomar posesión de ella y defenderla con sus vidas. Benito Juárez, más tarde, estableció más colonias de este tipo.

Los habitantes de las colonias eran privilegiados en muchos sentidos en comparación con las comunidades campesinas del centro y sur. No habían sido pupilos de la Corona durante el periodo colonial, sino que gozaron de derechos generalmente reservados a los españoles y a sus descendientes, los criollos. Eran propietarios individuales de sus tierras y tenían derecho de venderla o a comprar tierras adicionales. Generalmente poseían más tierras y más ganado que los campesinos libres de otras regiones. En el norte de México, el casco de las haciendas estaba diseñado para servir de refugio y fortaleza y enviando a sus hombres a combatir a las bandas merodeadoras (Ortelli, 2017: pp. 15-17). . La larga guerra contra los apaches concluyó cuando estos fueron derrotados en 1885 (Katz, 2016: pp. 14-16).

Independientemente de su ineficacia o eficacia como entidades defensivas, las compañías presidiales ejercieron una gran influencia debido a que los presidios se convirtieron en núcleos

6 Afirma Sara Ortelli que a quienes beneficiaba el estado de guerra, con su sistema presidial, era a los grupos locales, pues con el pretexto de la defensa encontraron la forma de obtener ingresos provenientes de la Corona, a través de los situados. Esta trama de intereses personales y corporativos de las provincias se vieron amenazados con las reformas borbónicas. 
poblacionales, un mercado para los productos de ranchos y de las misiones. El proceso de militarización de las fronteras se convirtió en un proceso beneficioso para la economía de la región (Almada Bay et al., 2007: p. 257).

\section{LA MEDICINA NOVOHISPANA EN EL ÚLTIMO TERCIO DEL SIGLO XVIII}

En los tiempos que don Antonio Comadurán ejerció la medicina prevalecía el ambiente cultural del siglo de las luces. Señala el destacado historiador de la ciencia argentino José Babini que las dos premisas sobre las que se basaba el pensamiento científico del siglo XVIII eran la razón y la naturaleza, y como enlace entre ambas la matemática, fruto de la razón y medio eficaz para sondear los secretos de la naturaleza. De esa manera "con el método experimental, la naturaleza se mostraba manuable y penetrable, lista para ser explotada”. Dicho proceso había sido en gran medida "un esfuerzo racional de orden matemático: de ahí la confianza, a veces excesiva, que el siglo XVIII otorgó a la razón humana" (1971b: pp. 7-8).

En el último tercio del siglo XVII destacó en la medicina Thomas Sydenham (1624-1689), "el Hipócrates inglés”, que acepta la vieja norma de la virtud curativa de la naturaleza, deja de lado toda especulación teórica, vuelve a la cabecera del enfermo y estudia la enfermedad en el enfermo mismo. En sus obras completas de 1685 describe numerosas enfermedades, una lleva su nombre, y nuevas prescripciones: preparados de hierro para la anemia, la corteza del árbol de la quina proveniente del Perú para las fiebres, la fórmula del láudano, extracto del opio, para aliviar dolores. ${ }^{7}$

El siglo asiste además a la introducción de otras drogas exóticas y de algunas novedades terapéuticas: las inyecciones endovenosas y los primeros intentos de transfusión de sangre, que se abandonan ante los peligros que acarrean; la aparición de los fórceps; una mayor respetabilidad de la cirugía y de los cirujanos;

7 El médico militar Fernando Ocaranza, señala que una circunstancia que favoreció el advenimiento de mejores días para la ciencia médica fue la persecución de charlatanes y curanderos por parte de la Inquisición (2011: p. 150). 
y la especificación de varias enfermedades como el raquitismo, la tuberculosis pulmonar y el beriberi (Babini, 1971a: pp. 89-90). ${ }^{8}$

El método directo de observación y experimentación rindió frutos de inmediato en la medicina, aunque su progreso fue lento. La noción de que la medicina era una ciencia para hacer descubrimientos en el estudio de los pacientes, más que una doctrina que se ponía en práctica en ellos, aunque era tan antigua como Hipócrates (460-357 a. C.), había sido olvidada por mucho tiempo. Pero en ese periodo dicha noción volvió a ser sustentada por algunos médicos, como Sydenham, quien, además de ser un gran clínico, estuvo en contacto con toda la ciencia de su tiempo.

La formación de los cirujanos se institucionalizó con la formación de los Colegios Reales de San Fernando de Cádiz, de Barcelona (1760) y de San Carlos de Madrid (1774), donde se prepararían los futuros cirujanos militares que atenderían las necesidades sanitarias y médicas de los cuerpos armados de la Real Marina y del Ejército. La cirugía pasó de ser una actividad manual en una disciplina profesional. La dinastía de los borbones favoreció la introducción del conocimiento ilustrado y con ello, dio cause al proceso educativo modernizador. El fundador de los Colegios de Cádiz y Barcelona fue el célebre e influyente cirujano don Pedro Virgili. Su sobrino Andrés Montaner y Virgili fue quien presentó el proyecto de reglamento del Real Colegio de Nueva España en 1772.

Con el advenimiento del pensamiento ilustrado se rompió el letargo de la medicina y de la cirugía que se impartía en las universidades españolas. El currículo académico en la Real y Pontificia Universidad de México tenía como base las doctrinas hipocráticogalénicas que partían del postulado de que la salud del cuerpo dependía de mantener el equilibrio de los cuatro humores de que se componía: la bilis negra, que era fría y seca; la bilis amarilla o roja, que era caliente y seca; la sangre caliente y húmeda; y la flema, fría y húmeda.

La renovación de la ciencia española estuvo encabezada por los novatores, un grupo de médicos, cirujanos, boticarios, así como

8 Por falta de vitamina B, el paciente sufre molestias estomacales, edemas múltiples, parálisis y trastornos nerviosos, estos son los síntomas del beriberi. 
algunos personajes de la nobleza y el alto clero, quienes en las últimas décadas del siglo XVIII tomaron conciencia del atraso en que se encontraba la ciencia española con respecto a los demás países europeos. En el ámbito médico-quirúrgico, los novatores cuestionaron los conceptos de Galeno e Hipócrates, revaloraron doctrinas como las vesalianas y las prácticas anatómicas como medios del conocimiento de observación directa. Al mismo tiempo, discutieron modernas teorías como las iatroquímicas sobre el funcionamiento del cuerpo humano: o la circulación de la sangre del inglés William Harvey (1578-1657) tuvieron especial interés en las ideas de Thomas Sydenham y Herman Boerhaave (1688-1738) quienes promovían la experimentación, la observación clínica y la concepción anatomopatológica. Los textos de estos autores fueron autorizados para su consulta, lo mismo que los de Lorenzo Bellini y John Brown. Asimismo, señalaron que la enfermedad residía en un órgano alterado que el medico debía saber diagnosticar para darle el tratamiento adecuado. Las nuevas necesidades del imperio llevaron a que la práctica quirúrgica pasara de un arte manual a una disciplina científica mediante la institucionalización de sus conocimientos. Una buena parte de los egresados de los Colegios de Cádiz y sobre todo de Barcelona, llegaron a Nueva España asignados a los diferentes cuerpos militares.

Al incluirse las clases de Anatomía a través de un disector anatómico se enriquecieron los conocimientos de la práctica médica y quirúrgica. En cuanto a la Botánica se tomó en cuenta una rica tradición herbolaria de los pueblos indígenas. ${ }^{9}$ Fue así como se partió de un conocimiento de una rica tradición herbolaria que desde antes de la conquista poseían los pueblos indígenas. Algunos de los cirujanos como don Ignacio León y Pérez, profesor de Farmacia y nombrado primer cirujano del Hospital Militar de Monclova en 1791, emprendió un proyecto con el fin de colectar

9 Señala Alfonso Reyes sobre "Nuestro Francisco Hernández/--el Plinio mexicano de los mil quinientos--/logró hasta mil doscientas plantas mágicas/de la farmacopea de los indios" (pp. 12-13). Los cirujanos de finales del siglo XVIII tenían una formación basada en el conocimiento de causa de las propiedades probadas de las plantas medicinales, como lo demuestran las listas enviadas a la Real Hacienda por parte de los médicos de los hospitales militares (2012: pp. 12-13). 
plantas y semillas y así, enriquecer el jardín botánico de la Ciudad de México, mientras se concluían las obras del hospital al que fue asignado (AGN, Caja 3476, exp. 5, 11 f.). ${ }^{10}$ Señala Carlos Sáenz de la Calzada que el médico Manuel Eulogio Carpio (1791-1860), poeta, traductor y crítico de Hipócrates, nos ofrece una visión irónica, pero cierta, de la práctica médica en el México del primer tercio del siglo XIX:
"Método de nuestros días,
luego que algún mal asoma:
agua de malvas y goma,
sanguijuelas y sangrías.
A mí me duelen las muelas,
mi hijo tiene tabardillo,
papá se quebró un tobillo...
Pues a todos sanguijuelas".

Se dice que, por entonces en Francia, Víctor Broussais, célebre difusor del brownismo, ${ }^{11}$ llegaba al hospital militar, preguntaba al médico en guardia: ¿Cuántos enfermos nuevos? Si este le respondía que diez, le recomendaba trescientas sanguijuelas, es decir, treinta por cada enfermo (Carlos Sáenz de la Calzada, 1971:157-158).

10 AGN. Indiferente Virreinal. Hospitales. Escribe desde Coahuila al Virrey que "le estimula el deseo de servir al Real Jardín y teniendo el obstáculo del peligro mortal de los enemigos apaches que combaten este valle, el quebranto de su salud se ve en la necesidad de suplicar se sirva concederle licencia para poder pasar libremente a la villa de Monclova o a la de Saltillo, a que siendo estas tierra menos propensas a enemigos y distintas de clima lo que al mismo tiempo al desempeñarse dicha comisión y restablecer su salud, en tanto llega establecerse el hospital, a que vino asignado, así mismo emplear este tiempo en el útil servicio. Dios Guarde a Vuestra Majestad muchos años. Santa Rosa, 18 de febrero de 1793.

11 El médico escocés John Brown consideraba a los seres vivientes en eterno conflicto con diversas potencias, internas y externas, de cuyo equilibrio conveniente dependía la salud. Los tres estados de salud, enfermedad y predisposición, constituyen la vida..." Carlos Sáenz de la Calzada (1971: pp. 150-151). 


\section{LOS HOSPITALES MILITARES DE ARIZPE Y CHIHUAHUA}

\section{Hospital Militar de Chihuahua}

El terreno donde se levantó el Colegio de Jesuitas fue donado por doña María de Apresa en 1718 y su construcción se llevó a cabo entre 1751 y 1752, la cual corrió a cargo de José de la Cruz. El Colegio, junto con la parroquia, ahora catedral, eran los edificios más vistosos de Chihuahua. [Recuérdese que la Compañía de Jesús había sido suprimida en España y en sus territorios allede el mar en 1767]. En 1779 se acondicionó para cuartel, escuela de primeras letras y hospital (Cramaussel, 2017: pp. 150, 152).

Los insurgentes con Miguel Hidalgo a la cabeza fueron capturados el 21 de marzo de 1811 en el paraje Norias de Acatita de Baján y trasladados a Chihuahua. Los aposentos del Real Hospital Militar fueron su cárcel. Del 10 de mayo a 27 de julio fueron fusilados en las paredes de sus muros dieciocho insurrectos, finalmente tocó su turno al caudillo el mismo día 27 (Márquez Terrazas, 2010: pp. 152, 171-172).

En 1779, el caballero Teodoro de Croix, comandante general de las Provincias Internas, comisionó al ingeniero Manuel Mascaró para elaborar un proyecto de hospital militar que aprovechara las instalaciones del ex Colegio de Jesuitas. El Virrey Conde de Revillagigedo resolvió que el Hospital Real Militar de la Villa de Chihuahua se estableciera en el Colegio de los Regulares expulsos, y determinó el 1 de mayo de 1790 que se hicieran en él las obras necesarias, para lo que dio orden y comisión al ministro tesorero don Domingo de Beregaña. En esa inteligencia previene a Jacobo Ugarte y Loyola entregue las llaves del referido colegio para que se dé mandamiento a dicha orden.

El 23 de agosto de 1790, Ruiz de Bustamante respondió que entregó llaves al tesorero Domingo de Beregaña y le previno que solo se abrieran "aquellas piezas del colegio que el cirujano don Antonio Comadurán señale como precisas para establecer el [h] ospital". Las demás quedaron disponibles para encerrar y custodiar la librería y muebles que están inventariados hasta verificar su entrega a quien corresponda. Le comunica que en cuanto a 
las alhajas y demás existentes en ella "quedará todo por aora [sic] como de presente está y establecido el hospital y nombrado el capellán que haya de servir en él, dispondrá reciba este la iglesia, con lo demás anexo a ella”.

El ingeniero militar catalán Miguel Constanzó (1741-1814) hizo las adaptaciones. Para enero de 1791, el hospital abre sus puertas, se supone que bajo la dirección del doctor Gregorio Arriola.

El Archivo General de la Nación resguarda un plano con la propuesta, enviada al virrey José de Iturrigaray, hecha por el maestro albañil y carpintero Francisco Acosta, con los materiales y gastos que se necesitan invertir, en el año de 1803.

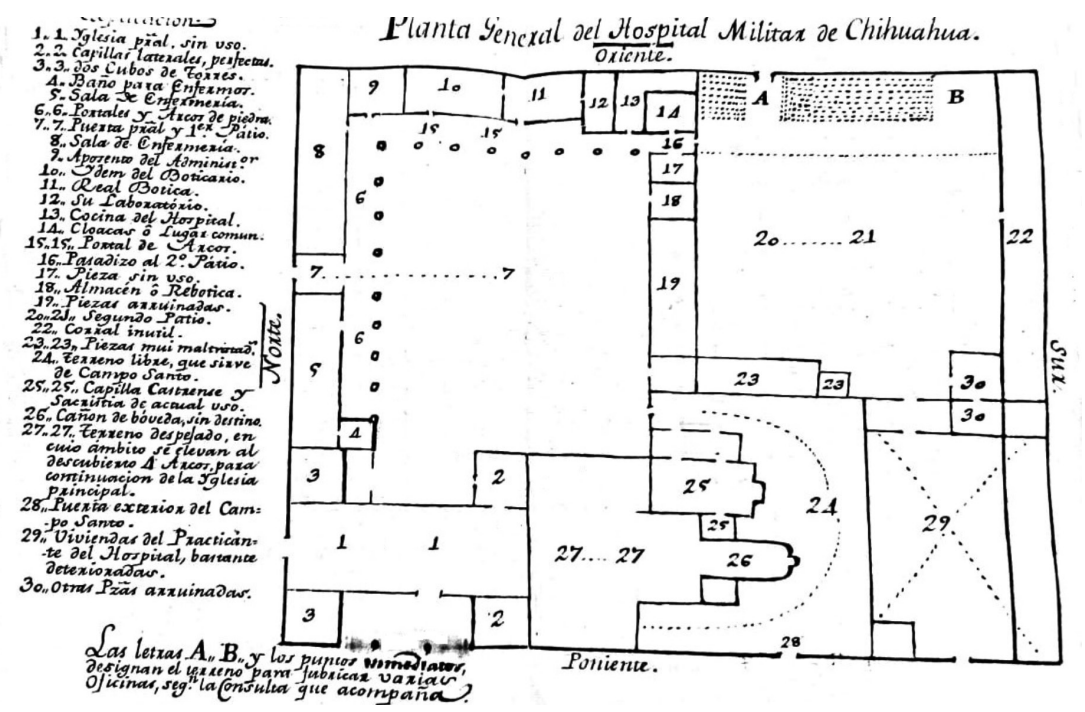

Fotografía del plano con la propuesta del maestro albañil Francisco Acosta para el hospital de la Villa de Chihuahua en 1803 (AGN Indiferente Virreinal. Hospitales, caja 3983, exp. 009, año 1803, 14f.).

En 1822 el hospital fue clausurado por falta de médicos. Se logró su reapertura en 1824 con el cirujano Francisco López de Roda. Zacarías Márquez Terrazas (2010: p. 208). Recién asumido el cargo de Comandante General de las Provincias Internas, el Brigadier Nemecio Salcedo, cumple con la disposición real de propagar la vacuna contra la viruela en las provincias bajo su mando. Para 
ello, se recurrió a un procedimiento ingenioso: para que no se agotara la corta cantidad de pus vacuno que se había remitido de Madrid, cada semana se vacunaron seis niños en Chihuahua, una vez que la inoculación maduraba se transmitía de brazo en brazo a otras personas y con esa periodicidad se vacunaron a cerca de dos mil habitantes en un ciclo de 12 años. Se encargaron de dirigir y vigilar las operaciones de vacunación el Regidor Joaquín Marichalar y el Síndico José Antonio Pérez Ruiz, bajo la vigilancia del doctor Jaime Gurza. La tercera vez que se recibió pus vacuno en 1824 la vacunación fue supervisada por el médico Francisco López de Roda (Almada, 1955: pp. 136-137).

Hasta que entró en vigor el reglamento hospitalario en 1774, los hospitales militares contaron con un administrador y con la ayuda de un sangrador (Ramírez Ortega, 2010: p. 309). Aún así, la carga de trabajo de los cirujanos militares llegó a ser abrumadora. Tenía que dar su visto bueno a los requerimientos del administrador del hospital, del boticario y de los trabajos de restauración y acondicionamiento.

El hospital militar de Chihuahua, establecido en 1790 en el excolegio de los jesuitas, llegó a contar con el reglamento que debía regir en el hospital militar de Arizpe (p. 269). Suponemos lo anterior porque el hospital militar de Arizpe aún no estaba edificado en 1791 (AGN, vol. 517, exp. 4, 1 f.). ${ }^{12}$

Durante la gran campaña filantrópica de vacunación, el cirujano Jaime Gurza y Vigo aplicó a un número considerable de personas, la vacuna contra la viruela en una sala del hospital real militar de Chihuahua en 1799 y 1801. El servicio se extendió al resto de Chihuahua y Sonora (Ramírez Ortega, 2010: pp. 284-285). Afirmamos que en Arizpe debió participar Comadurán, aunque no hemos encontrado la referencia correspondiente.

12 AGN. Archivo Histórico de Hacienda. El Intendente Gobernador de Sonora Henrique de Grimarest, acusa recibo del nuevo formulario del estado general de población que V E dirige el 8 de marzo de 1791. La respuesta es contundente: no hay colegios, hospitales, casas de misericordia y cárceles. Arizpe, 7 de mayo de 1791. Al virrey Conde de Revillagigedo. Este testimonio comprueba que para el año de 1791 aún no estaba instalado el hospital real militar de Arizpe. Es decir, ya habían pasado cinco años de haber sido nombrado Arreola como cirujano de esta localidad. Por el contrario, Chihuahua ya contaba con edificio en 1790 . 
Las dietas en los hospitales militares eran por reglamento: atoles, champurrado o chocolate en la mañana, a media mañana dos sopas y su olla con 12 onzas de carnero asado, a los enfermos con dieta se les proporcionaba caldo de gallina, pan y medio cuartillo de vino y la sopa necesaria (pp. 284-293).

Una práctica recurrente de los cirujanos de esa época era prescribir baños termales a los pacientes, como se venía haciendo en reinos europeos desde principios del siglo XVIII. Por ejemplo, el cirujano de las tropas de Sonora, don Antonio Comadurán mandó que se tomaran baños sulfúricos de Aconchi a varios soldados de los presidios de Santa Cruz en 1796 (AGN, Caja 4949, exps. 030-032). ${ }^{13}$

Tenemos constancia documental que los tratamientos regulares de la época era la prescripción de baños en aguas termales para pacientes artríticos, con infecciones de la piel y otras molestias. En tanto que, para la sífilis, el método más recurrente era el tratamiento con unciones de mercurio (Ramírez Ortega, 2010: p. 108).

Los cirujanos de Arizpe y Chihuahua contaron con el apoyo del doctor Antonio Serrano, cirujano mayor del Hospital Real de los Naturales, quien estaba preocupado por el avance de la cirugía y estaba comprometido por el buen establecimiento de los hospitales militares y dotarlos de una caja completa de instrumentos para toda clase de operaciones (p. 226).

Las enormes distancias que separaban a las poblaciones septentrionales condicionaron una difícil comunicación entre los cirujanos que en ellas servían Arizpe, Chihuahua, Durango, Monclova, por ejemplo. Los cirujanos dieron prueba de una clara vinculación institucional al contribuir al mejoramiento de las instalaciones, tanto informando sobre las necesidades y requerimiento de materiales de curación, de surtir la botica y la compostura material de los locales (p. 305).

13 AGN. Indiferente Virreinal. Indiferente de Guerra. Una cura prodigiosa se operó en el músico alemán Jorge Federico Händel, quien a sus 52 años sufrió en su casa de Londres un ataque de apoplejía en 1737. Cuatro años después, su médico londinense Cristopher Schmidt, sin saber qué hacer ante un caso incurable se le ocurrió aconsejar que lo llevasen al balneario de Aquisgrán, Alemania, para ver si las aguas termales le podían proporcionar alguna mejoría. Por su tenacidad Händel recuperó su salud. Luego de que "resucitó" sobrevivió otros 18 años, para gloria de la música (Sweig, 1967: pp. 65-89). 
Según Francisco R. Almada (1968: p. 256), el primer Hospital militar en establecerse en Chihuahua se debió a la iniciativa del Brigadier Jacobo de Ugarte y Loyola, Comandante General de provincias internas. Los hospitales militares estaban destinados a atender a los heridos y enfermos de las fuerzas destacadas en diversas poblaciones fronterizas de la Nueva Vizcaya que luchaban en contra de apaches y comanches. El 4 de marzo de 1790, el Virrey, 2. ${ }^{\circ}$ Conde de Revillagigedo autorizó la fundación del Hospital en la Villa de Chihuahua. Se adaptó el excolegio de la orden de los jesuitas para tal fin. El edificio fue entregado por el administrador de temporalidades al ministro tesorero de Real Hacienda, don Domingo de Beregaña.

Almada señala erróneamente que se encargó del acondicionamiento el doctor Gregorio Arriola, y que asumió la dirección del hospital y que después lo reemplazó el doctor Antonio Comadurán y a este siguieron los doctores Juan B. Crivelli y Jaime Gurza (p. 256). No hay evidencias que Arriola haya fundado el hospital militar de Arizpe, y casi al mismo tiempo Comadurán el de Chihuahua, de manera que este recibe las llaves y se encarga de dicho acondicionamiento del hospital de Chihuahua, como veremos más adelante. Ambos no podían ser directores de los hospitales, porque éstos contaron con un administrador desde un principio. ${ }^{14} \mathrm{El}$ Comandante General Ugarte y Loyola instruye a Juan José Ruiz de Bustamante el 21 de agosto se proceda a ejecutar la entrega para el formal inventario de bienes, lo mismo que en vasos sagrados, ropa de imágenes y de las bancas, mesas, sillas, y demás muebles que se consideren útiles para el servicio de referido hospital. El 23 de agosto, Ruiz de Bustamante le responde que entregó llaves al tesorero Domingo de Beregaña y le previno que solo se abrieran "aquellas piezas del colegio que el cirujano don Antonio Comadurán señale como precisas para establecer el [h]ospital”. Las demás

14 Es pertinente señalar aquí, que durante toda nuestra investigación no encontramos ninguna otra noticia sobre Gregorio Arriola en documentos de la época más que el mencionado en la nota 46 y que se encuentra en el Archivo General de la Nación, desde ese nombramiento desaparece la pista de este doctor, y es curioso que el mismo Almada no dé tampoco ningún dato biográfico sobre él en los diccionarios chihuahuense y sonorense. 
quedaron disponibles para encerrar y custodiar la librería y muebles que están inventariados hasta verificar su entrega a quien corresponda. Le comunica que en cuanto a las alhajas y demás existentes en ella "quedará todo por aora [sic] como de presente está y establecido el hospital y nombrado el capellán que haya de servir en él, dispondrá reciba este la iglesia, con lo demás anexo a ella" (AGN, t. 57, exp. 5, ff. 132-140). ${ }^{15}$

Ruiz de Bustamante informó el 9 de septiembre a Ugarte, que ya hizo entrega al ministro de Real Hacienda de las llaves de las piezas que tenga a bien señalar el Cirujano Don Antonio Comadurán para el Hospital Real Militar que va establecerse en el colegio de los regulares expulsos de la Villa de Chihuahua. Se entregaron diez bancas, tres mesas, dos camas de bancas con tablas, seis taburetes y un armario "todo maltratado aunque servible". Señala que en una de las piezas "existe una dilatada librería de mui [sic] crecido volumen que no tengo donde colocarla". Ese mismo día Ugarte dio su visto bueno a Ruiz de Bustamante por proceder a la orden de hacer entrega de las llaves correspondientes al cirujano Comadurán y que hasta nuevo aviso del Virrey, la librería habrá de permanecer resguardada en el cuarto donde actualmente se haya.

Juan José Ruiz devuelve el 17 de julio de 1794 el inventario a Pedro de Nava, donde se expresan los ornamentos, imágenes, vasos y demás pertenecientes al colegio de regulares expulsos que fueron entregadas el 16 de abril de 1793 en cumplimiento de orden verbal de don Juan de Dios Calderón, administrador del Real Hospital Militar de Chihuahua. Los ornamentos serán destinados para el uso de la capilla castrense.

Aunque falta cotejar cuándo se graduó Comadurán, tal vez alrededor de 1780, de Licenciado en Cirugía en el Real Colegio de Barcelona, fundado en $1760 .{ }^{16}$ Los pretendientes a ingresar a los reales colegios de Cirugía debían demostrar su limpieza de san-

15 Temporalidades: Bienes enajenados a los jesuitas. Hospital Militar de la Villa de Chihuahua.

16 Señala Pierre Vilar (2011: p. 91): “La Cataluña del siglo XVIII conoció un alto nivel de preocupaciones culturales en dominios como las ciencias naturales, la medicina, las técnicas agrícolas e industriales y también el derecho y la teología”. En este contexto se entiende el establecimiento del Colegio de Cirugía de Barcelona. 
gre, es decir, hacer probanza de ser hijos legítimos de matrimonio legítimo, descendiente de familias de cristianos viejos, saber leer y escribir y tener buenas costumbres. El ejercicio de la cirugía era considerado un oficio noble. Los cirujanos egresados de los reales colegios gozaban de ciertos privilegios, el tratamiento de "don", ostentar la prerrogativa del uso de uniforme, bata larga cuando ejercieran el oficio y el uso de bastón. Quizá Comadurán ejerció su oficio en España antes de llegar a la Nueva España entre 1785 o 1786. Cuando en 1786 fue nombrado cirujano de los reales ejércitos en Chihuahua, contaba con 39 años de edad. Es muy probable que llegara a la Nueva España asignado al servicio del cuerpo militar de Voluntarios de Cataluña.

El desplazamiento de escalas, desde el movimiento trasatlántico de un catalán en la metrópoli hispana, regida por los borbones; su traslado marítimo a la capital de la Nueva España; de aquí a Provincias Internas: Chihuahua y Arizpe, ciudades que forman una región en la que Comadurán vivirá 30 años en tierras amenazadas por indios en guerra. En Chihuahua fundó una familia, en cuyo seno concluyen sus días a los 69 años de edad, rodeado de hijos y nietos. El relato de vida está basado en una acuciosa búsqueda genealógico-prosopográfica.

El documento más antiguo sobre su carrera en "Indias" está fechado el $1 .^{\circ}$ de noviembre de 1786. Real cédula que aprueba los nombramientos hechos a favor de don Gregorio Arriola para cirujano de Sonora y a don Antonio Comadurán Cirujano de Chihuahua, en las Provincias Internas. Esto significa que antes que se formara el hospital militar Comadurán ya era cirujano de Chihuahua (AGN, vol. 135, exp. 95. ff. 211-211v). ${ }^{17}$

Dicha aprobación real fue recibida en el despacho del Virrey Bernardo de Gálvez el 13 de marzo de 1787. Probablemente ese

17 AGN. Reales Cedulas Originales: "En vista de la carta de V.E. del 30 de junio de este año, ha venido el rey en aprobar los nombramientos que V.E. ha hecho a don Gregorio Arriola y a Don Antonio Comadurán para cirujanos de Sonora y Chihuahua, pero reduciendo el sueldo anual de mil pesos que V.E. les asigno al de sesenta pesos mensuales. Participolo a V.E. de su real orden para su inteligencia y cumplimiento. Dios guarde a V.E. muchos años. San Lorenzo $1^{\circ}$ de noviembre de 1786. Según el arancel para protomédicos era en 1759 de 61 pesos, cuatro reales, 1 tomín, 6 granos (Flores y Troncoso, 1982, p. 51). 
mismo año se traslada a Chihuahua. Donde a principios de 1789 contrae matrimonio con Ramona, la hija del avezado Capitán Antonio Díaz de Carpio.

En el cuadro siguiente haremos referencia de los cirujanos que ocuparon plaza en los hospitales militares de Arizpe y Chihuahua, destacando desde luego, al cirujano barcelonés don Miguel Antonio Comadurán Rovira, quien jugó un papel destacado en ambos hospitales.

Cuadro 1. Lista de cirujanos. La mayoría de origen catalán.

Hospitales Militares, 1790-1821.

Hospital Militar de Arizpe. Hospital Militar de Chihuahua.

Cirujanos:

Cirujanos:

1. Gregorio Arriola, ¿1791? 1. Antonio Comadurán, 1790-1795.

2. Antonio Comadurán, 1795-1806. 2. Sebastián Barceló, 1791-1797

(ayudante de cirujano mayor).

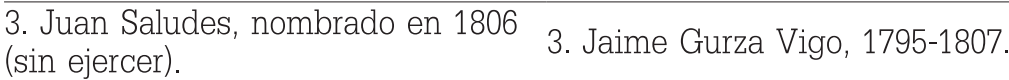

4. Jaime Gurza, ¿1806?

4. Juan Bautista Crivelli, 1796-1802.

12 de octubre de 1796-1802 (6 años,

4 meses, 17 días).

5. Francisco López, 1806-1807. Se traslada al hospital de Arizpe, que no tenía facultativo desde que Gurza 5. Francisco López, 1804-1806. se trasladó a Chihuahua.

6. Juan José Siqueiros, 1815 (enfermero desde 1796).

5. Antonio Comadurán, 1807-1814.

7. Francisco López de Roda, 1818- Francisco Millán, 1814- 1815 1822.

(practicante).

7. José María Navarro Verdugo, 1818-1820.

8. Antonio Romá de San

Germán, 1820-1821. Cirujano

barcelonés, participó en campañas

contrainsurgentes en Nueva

Santander contra las tropas de Mina

y en el Bajío. 
El 7 de diciembre de 1818 el cirujano José María Navarro fue nombrado inspector facultativo del Hospital Militar de Chihuahua. Poco después recibe real orden del virrey Apodaca, quien le solicita estado circunstanciado de dicho hospital. En su reporte de agosto de 1819, Navarro señala que encontró el hospital en el mayor grado de abandono y miseria. Fue necesario tener varias discusiones con el oficial real de aquellas cajas (AGN, t. 64, exp. 9, ff. 142-145).

\section{ANTONIO COMADURÁN. CIRUJANO DE LOS REALES EJÉRCITOS}

La prosopografía nos permite aproximarnos a la historia de vida de un personaje en su contexto de relaciones sociales (redes) su acción es un hilo conductor que nos explica una época, una familia, una generación y múltiples vínculos culturales, gestados en una misma sociedad (Acevedo Tarazona, 2013: p. 202).

Miguel Antonio Comadurán Rovira fue hijo legítimo de legítimo matrimonio de don Joseph Comadurán i Pujols (1722-1770) y de doña María Rovira i Macaya (1711-1786). Nació en 1747 en la ciudad condal de Barcelona, Principado de Cataluña, y bautizado en la parroquia de Santa María del Mar; le siguieron sus hermanos Josep (1748), Francesc (1749), Teresa (1756) y Gerau (1760). Se casó con Ramona Díaz del Carpio y Aguirre en 1789 en la iglesia de San Francisco, Chihuahua, el 4 de febrero. Doña Ramona nació el 12 de enero de 1772 en Santa Cruz de Rosales, Chihuahua, hija del veterano capitán de Presidio don Antonio Díaz del Carpio (AGN, vol. 38, exp. 26, ff. 55-56, 1751). ${ }^{18}$ Sus primeros tres hijos

18 “V. exa. Juan Francisco de Güemes nombra por capitán del Presidio de Terrenate a don Joseph Díaz de Carpio, por la remoción de su antecesor, Don Santiago Ruíz. Le conviene al servicio de ambas majestades y de la causa pública y particular el que los capitanes de los presidios internos muden residencia. Don Joseph Díaz de Carpio, capitán del Real Presidio de Janos, pase luego que reciba despacho a servir la plaza de capitán del Real Presidio de Terrenate, en que lo proveo y lo nombro que se encargue de su compañía para que en la misma conformidad que lo hacía en la anterior que era a su cargo practique y ejecute el real servicio en las ocasiones que se ofrezca, y a este fin mando al teniente Alférez y demás cabos y soldados de ella le reconozcan por tal capitán, le acaten, respeten y obedezcan, guarden y cumplan sus órdenes y mandamientos...gozando de todas las gracia, honras, franquezas y libertades de su cargo". Por cierto, Francisco Elías González de Zayas, comandante del presidio de 
Comadurán y Díaz del Carpio nacieron en Chihuahua. Los dos siguientes nacen en Arizpe en 1795 y 1797. Las dos últimas hijas nacen en Chihuahua en 1804 y $1805 .{ }^{19}$

La familia de Comadurán Rovira, la cual se dedicaba al comercio de ultramarinos debió gozar de una situación holgada, por lo que podemos suponer que el infante Antonio y sus hermanos tuvieron una educación impartida por un preceptor privado. Cuando Antonio llegó a ser un muchacho letrado se inclinó por los estudios de medicina, tal vez influido por su padre boticario. Para ello solicita su inscripción en el Colegio de Barcelona, que había abierto sus puertas en 1760 por reglamento de 12 de diciembre de ese año, que quedó establecido y que funcionaría en el Hospital Real de la Plaza de Barcelona, donde se enseñaría en esta facultad la cirugía según ya se venía practicando en el Colegio de Cádiz, fundado en 1748.

Los alumnos del nuevo colegio fueron estudiantes y practicantes de cirugía de las localidades cercanas, entre ellos los mancebos de las tiendas de boticas, quienes permanecían en calidad de externos, pero con las mismas obligaciones que los internos. Al término de sus estudios de no menos de seis años, y aprobado el examen recibían el grado de bachiller y título de cirujano latino o latinista, ya que habían estudiado latinidad, lógica y filosofía. Al término de sus estudios era necesario iniciar sus servicios como cirujanos segundos en los navíos de la Real Armada.

El pasaporte que se concedía para viajar a Indias era un documento expedido por el teniente general de la real armada, y encargado de la Secretaría de Estado, de Guerra, Hacienda, Comercio y Navegación de Indias (Rodríguez-Sala, 2005: pp. 277-278). Los cirujanos enviados desde la metrópoli llevaban consigo pagas por adelantado, en algún caso sus familias y todo su instrumental y sus propios libros de su facultad (p. 79). Al parecer Comadurán

Terrenate, se casó con María Francisca, otra de las hijas del capitán Joseph Díaz del Carpio, quien también había sido capitán del presidio de Janos. El presidio de Terrenate estuvo en funciones de 1724 a 1775 (Officer, 1989: p. 40).

19 Investigación genealógica de Martín Clavé Almeida en los archivos parroquiales del Sagrario de Chihuahua, de ciudad Guerrero, Bachíniva, Aldama y otros archivos civiles del estado de Chihuahua, en el AGN y en PARES. 
viajó antes de 1786 a la Nueva España sin familia, es decir, en calidad de soltero. No sabemos en qué año se enlistó en los navíos de la Armada Real, debido a su condición, ya que un cirujano militar debía ser apto para el servicio de las armas.

En 1770, el rey señaló que el uniforme de los cirujanos militares consistía en casaca, chupa y calzones de color canela, botón de metal dorado con collarín y vuelta de terciopelo negro. En 1775, el sueldo de cada cirujano quedó establecido en 40 pesos mensuales, diez pesos más que los capellanes, pero diez menos que los capitanes fusileros (Rodríguez-Sala, 2005: pp. 50-51).

En 1786 los cirujanos militares Antonio Comadurán y Gregorio Arriola, probablemente su compañero de estudios durante la carrera de cirugía, ya estaban establecidos en la Nueva España, ya que ese año fueron propuestos por el propio virrey como médicos militares para Chihuahua y Arizpe, plazas donde se establecerían los Hospitales militares. Primero en Chihuahua en 1790 y poco después en Arizpe. La llegada de ambos a las áridas tierras del septentrión, en el que predominan ambientes insalubres, hostilizado por indígenas en guerra, obedece al proyecto borbónico de dar cierta regularidad a las fuerzas armadas, sobre todo cuando se implementan los sistemas de Intendencias en 1786. Su escenario geográfico en el que actuará son las Provincias Internas de Occidente: Sonora y Nueva Vizcaya. Las ciudades de Arizpe y Chihuahua llegaron a ser las capitales de la Comandancia General. Los cirujanos que eran destinados al hospital militar de la plaza dejaban de pertenecer a un cuerpo militar específico, pero permanecían vinculados al ejército.

Antes de su llegada, los numerosos presidios que conformaron la línea de protección fronteriza acogían en cada uno de ellos una compañía reducida, que constaba por regla general de un capitán, un cabo, un sargento y entre un mínimo de once a un máximo de setenta y siete soldados, el promedio, antes de las reformas borbónicas era de menos de cincuenta soldados. Las milicias de la frontera llegaron a crecer inusitadamente como veremos más adelante. 
Cuando se establecieron los hospitales reales de Arizpe en las provincias internas de Sonora y Sinaloa y de Chihuahua, en la Nueva Vizcaya, se agilizaron los trabajos para enviar médicos cirujanos antes de su establecimiento en 1790. Cuatro años antes habían sido nombrados para esas plazas a Gregorio Arreola y a Antonio Comadurán, quienes debieron de llegar a sus adscripciones a principios de 1787. A pesar de que Arizpe adquirió gran importancia porque se convirtió en la capital de Comandancia general de la Provincias internas y en 1780, ya ostentaba el título de ciudad, aún no se había establecido su Hospital Militar en 1791.

Fotografía de las ruinas del hospital militar de Arizpe, tomada por

James E. Officer en 1982.

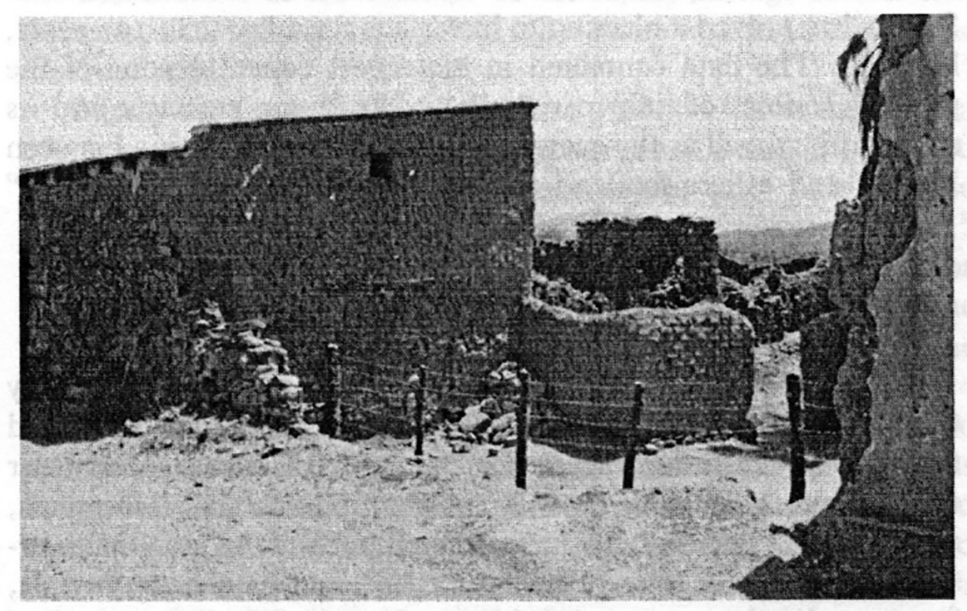

Ruins of the Provincias Internas military hospital in Arizpe (author's photograph taken in 1982)

Don Antonio Comadurán, licenciado en Cirugía y cirujano del Hospital Militar y tropas que guarnecen la frontera de Sonora, ${ }^{20}$ habiendo procedido del reconocimiento de la botica de dicho hospital militar, según se previene en su particular reglamento, en

20 A pesar de la importancia de Arizpe el edificio de su hospital fue construido de altas paredes de adobe y techado de teja, a diferencia del de Chihuahua que se estableció en el edificio exjesuita de mamposteo y cantera. Foto tomada por James E. Officer en su visita a las ruinas de dicho hospital en 1982 (1989, p. 69). 
consorcio del maestro Boticario Miguel Benítez de Lugo, elabora el 30 de junio de 1801 la lista de "medicamentos" necesarios. Al final, viene una nota donde pide extremar cuidados en el empaque y traslado de los materiales, para evitar averías. Los oficiales de Real hacienda obsequian su aprobación el 9 de noviembre de 1801. La petición tardó en llegar cinco meses y una semana. Si se tardó en llegar el correo ese tiempo y si de regreso hizo el mismo tiempo y calculando el surtido, el cirujano recibió su pedido entre mayo y junio de $1802 \ldots$ jun año después!

Entre los medicamentos de la larga lista se señalan toronjil, jazmines, romero, mejorana, alhucema, laurel, almendras amargas, bálsamo admirable, agua fuerte, espíritu de sal de amoniaco, arrope de moras, azogue, sumo de rosas, vinagre de vino fuerte, aceite común amarillo bueno, etcétera (AGN, vol. IV, caja O688, exp. 19, 1801). ${ }^{21}$

Don Miguel Benítez de Lugo, Maestro Boticario del Hospital Militar de la ciudad de Arizpe desde el 6 de junio de 1801, suplicó a los ministros de Real Hacienda de esta tesorería jubilación con el beneficio del Montepío. Justifica que desde hace ocho años se mantiene enfermo de una pierna; anexa la constancia de Dn. Francisco López de Roda, primer ayudante honorario de Cirugía del ejército y cirujano de este hospital militar:

Certifico en toda forma ser cierto que D. Miguel Benítez de Lugo hace mucho tiempo adolece de una ulcera sintomática en la pierna izquierda y sin embargo havérsele administrado por largo tiempo los remedios que juzgue más a propósito para la curación no se pudo conseguir, en mi concepto incurable, e impide al paciente andar. Francisco López. 24 de agosto de 1818. Declara Benítez, el 18 de noviembre de 1818 estar "casado, con casa propia y con más de 50 años, [que su] anhelo es que le ayude [su] corta pensión a [su] pobre mujer". 22

21 IV. Hospitales. Regio patronato indiano. Antonio Comadurán. Licenciado en ciencia y cirujano envía listas de medicamentos que hacen falta en el Real Hospital militar, que se encuentra en la Frontera de Sonora. Arizpe.

22 El canario Miguel Benítez de Lugo fue boticario de Arizpe, quien coincidió en los tiempos en que fue cirujano del hospital militar real, don Antonio Comadurán, es decir 
El documento demuestra que el boticario Benítez inició su servicio en el hospital militar de Arizpe en el tiempo en que el cirujano era Comadurán. Menciona que fue comisionado al ejército que fue a combatir a los insurgentes de 1810 a 1811, y que por este servicio se le siguió pagando como boticario y no como cirujano. Se basa en el antecedente de 1806, cuando don Antonio Comadurán se hizo cargo de la botica en el momento que el boticario, su antecesor, se retiró de este servicio. Dicho cirujano se hizo cargo de la botica, dándole 25 pesos mensuales, el tiempo que la sirvió, que es la mitad del sueldo de boticario, pareciéndome ser idénticas estas circunstancias (AGN, caja 4331, exp. 060, 1818, f. 5). ${ }^{23}$ La Real Junta determinó a fines de enero de 1819 que no tenía derecho de Montepío.

Comadurán tuvo la oportunidad de disfrutar de una amplia vinculación social y llegó a ser estimado por las comunidades de Arizpe y Chihuahua. Llegó a Chihuahua en 1786 y permaneció aquí hasta 1794 y para el siguiente año se hizo cargo del Hospital de Arizpe, donde llegó al lado de su numerosa familia que formó en Chihuahua. En 1806 pide su retiro para trasladarse de nueva cuenta a Chihuahua. Al parecer rebasaba los años requeridos para el servicio activo. Quizá cuando regresa en 1807 vuelve a hacerse cargo por poco tiempo del Hospital Militar en Chihuahua.

Suponemos que los diez últimos años de su vida, transcurridos en Chihuahua y retirado del servicio militar, hubo de ocuparse como cirujano civil, dedicado a consultas personales y visitas a domicilio, gozando del aprecio ganado durante el tiempo que fue médico del hospital militar.

de 1801 a 1806. Su última disposición testamentaria fue el 19 de octubre de 1820. Sus bienes declarados consistían: una casa en la plaza de oriente, 46 cabezas de ganado mayor y 3 caballos de servicio, a cargo de Santiago Fuentes de Chipapo, gozando el tercio de lo producido. Se le dará una vaca a la muchachita que vive en mi casa, hija de Francisco Mendoza, siendo de advertir que en poder del citado Santiago Fuentes se hallan cinco reses, pertenecientes a María Tomasa Duran (Tonella Trelles, 2000, pp. 102-104).

23 Indiferente Virreinal. Hospitales. Hospital militar de Arizpe. Miguel Benítez de Lugo, Maestro Boticario, pide a los ministros de Real Hacienda de la Tesorería principal se le expida certificado de servicios. 
Comadurán permaneció en Chihuahua hasta el final de sus días, abril de 1816. No sabemos en qué año murió su esposa Ramona Díaz del Carpio y Aguirre, con quien había contraído nupcias el 4 de febrero de 1789. Sabemos que era viudo al morir por el expediente de Bienes de difuntos donde el monte pio militar favorece a cinco de sus hijos que le sobrevivieron: los jóvenes Buenaventura, soltero, Antonio, el menor de 19 años, soltero, María Antonia de 21 años, doña Ramona y doña Luisa. Para entonces quedaron descartadas María Josefa de 27, casada con Juan José Trillo, Tomasa de 24, casada con el propio Toribio Do Porto, ${ }^{24}$ María Antonia y Antonio nacieron en Arizpe, la primera en 1795 y el segundo en 1797. Los demás nacieron en Chihuahua entre 1787 y 1791, según registros de las parroquias de Chihuahua y Arizpe. A mediados de 1806, Comadurán estaba asignado al hospital de Arizpe (AGN, caja 4428, exp, 28, 1816, 2 ff.). ${ }^{25}$ En este año estaba aprobado su retiro. Lo sustituye Francisco López (Rodríguez-Sala, 2005: p. 267).

Sobre su muerte tenemos noticia en el expediente de Indiferente Virreinal. Bienes de difuntos. (caja 3406, exp. 036. f. 2), que es una certificación parroquial:

Presbítero Dn José Miguel Salas, sacristán propietario de esta villa, cura interino de la dicha villa en ausencia del propietario don Juan Mateos Álvarez. Certifico en cuanto puedo y el derecho me permite, hallarse bajo el cuidado y asistencia de Don Toribio do Porto como tutor nombrado por el Sr. Comandante General, Mariscal de Campo, Don Nemecio Salcedo, los menores e hijos del difunto Don Antonio

24 Toribio Doporto, probablemente hijo de don Ventura Doporto, originario de Coruña (Galicia), fue alcalde de Chihuahua de 1781-1786 (English Martin, 2004: p. 323).

25 AGN. Indiferente Virreinal. Indiferente de Guerra: “El Dr. Don Mateo Sánchez Albares cura propio de esta villa certifico en quanto puedo y el derecho me permite sea cierto y constarse hallarse bajo el cuidado y asistencia de Don Toribio Do Porto como tutor nombrado por el Comandante General que fue de esta provincia, Mariscal de Campo Don Nemesio Salcedo, los menores hijos del difunto Don Antonio Comadurán y Rovira, cirujano del Hospital Militar, cuyos niños se hayan sin tomar estado y sus nombres son Doña María Antonia, Don José Antonio, Doña Ramona, Don Ventura y Doña Luisa, todas Comadurán En fe de lo que doy la presento a pedimento de Don Toribio Do Porto en Chihuahua a 31 de diciembre de 1816". 
Comadurán y Rovira, cirujano del hospital militar de esta villa, cuyos niños y niñas se hallan sin tomar estado, sus nombres son Doña María Antonia, Don José Antonio, Doña Ramona, Don Ventura y Doña Luisa. Toribio Do Porto, tutor y apoderado, recibe del Tesorero Interno, Don Manuel José Zuloaga. Son 71 pesos, un real y cinco granos por cada uno. 213 pesos que gozan anualmente del Montepío Militar. Chihuahua 31 de agosto de 1816.

Comadurán fue nombrado en 1786 cirujano de Chihuahua. Durante los años anteriores a 1790, cuando se funda el hospital, seguramente realizaba trabajo de inspección en los presidios lo más cercanos al presidio de San Felipe, dedicado a estos menesteres se relaciona con los capitanes de presido. Así conoce al militar veterano Joseph Díaz del Carpio. Para 1789, se casa aquí (4 de febrero) con una de sus hijas, Ramona Díaz del Carpio y nace ese mismo año su hija María Josefa. En 1791, nace su hija Tomasa y su primer hijo varón, Buenaventura, en 1793, también en Chihuahua. Luego de su traslado a Arizpe, allá nacen su hija María Antonia en 1795 y José Antonio en 1797. Ramona, nació en 1804 y Luisa la menor en 1806. En 1796 sale para Arizpe, y lo sustituye Gurza, quien ya estaba en Chihuahua en 1794, más tarde fue reemplazado por Crivelli, en 1796. A Crivelli lo nombran cirujano para 1803 en el Hospital Militar de San Carlos, Veracruz.

\section{CONSIDERACIONES FINALES}

Este seguimiento inicial de la trayectoria de vida del cirujano militar Antonio Comadurán es una prueba fehaciente de la proliferación del criollismo, como estilo cultural de vida que se estableció en Sonora y Chihuahua. Al analizar las oleadas migratorias controladas por la Corona metropolitana, podemos observar que solo hasta bien entrado el siglo XVIII lograron incursionar catalanes, desplazando a los vascos en las provincias de la Nueva Vizcaya.

Un catalán con profesión se convertía en un buen partido para las mujeres criollas, hijas de peninsulares. Este fue el caso del matrimonio de Antonio Comadurán Rovira con Ramona Díaz del 
Carpio y Aguirre, la hija del peninsular Joseph Díaz del Carpio. Las redes sociales en las que se desenvolvía nuestro cirujano militar tenían que ver con la vida que transcurre en los presidios. Desde esta perspectiva fue posible que se uniera en matrimonio con una hija del Capitán José Díaz del Carpio, quien dejó descendencia en Chihuahua y en Arizpe. En este tenor, José Antonio Comadurán y Díaz del Carpio fundó su familia e hizo carrera militar en el Presidio de Tucson, Arizona.

La biografía que hemos trazado del cirujano catalán Antonio Comadurán Rovira, nos muestra a un personaje de férrea voluntad, con el carácter para sobresalir en un entorno bélico y difícil. Su espíritu de aventura lo trajo a tierras del norte. Su desempeño como médico fue ejemplar, su sensibilidad humana le granjeó la estima de sus pacientes. Una muestra de la agresividad del medio, es que el grado de viudez de los presidios es impresionante, ya que de cada dos mujeres una es viuda, como lo demuestra la tesis de María del Carmen Tonella (2000), en torno a las mujeres en los testamentos registrados en los distritos de Hermosillo y Arizpe, Sonora de 1786 a 1861.

En este estudio de caso se deja entrever un claro liderazgo de peninsulares de primera generación, que favorecerán el criollismo muy peculiar de las tierras del Gran Norte. El padre de familia, un profesional médico, muy escaso en la región, legará a sus hijos una ascendencia muy marcada en territorio de guerra, como se refleja en su hijo Antonio Jr., prácticamente un patriarca en Arizpe y posteriormente en Arizona, último comandante mexicano, antes de que ese territorio fuera anexado por los EEUU.

\section{REFERENCIAS}

Fuentes documentales

Archivo General de la Nación (AGN).

Archivo de la Catedral de Chihuahua, libros de bautismos y defunciones. Libro castrense del presidio de San Carlos.

Archivo parroquial de Bachíniva, Chihuahua.

Archivo Municipal de Ciudad Guerrero, Chihuahua. 
Archivo parroquial de Aldama, Chihuahua.

Documentos del Archivo General de la Nación.

General de parte. Vol. 38, exp. 25, f. 52 (1751). Se nombra por capitán del presidio de Terrenate a Joseph Díaz de Carpio. Janos, Chihuahua.

Provincias Internas. Vol. 259, exp. 11, ff. 312-323 (1792). Diligencias para que se traslade una dotación de medicamentos solicitados por el hospital militar de la villa de Arizpe.

Reales Cedulas Originales. Vol. 135, exp. 95, ff. 211-211v. (1786). Aprueban nombramientos hechos a favor de don Gregorio Arreola para cirujano de Sonora y a don Antonio Comadurán Cirujano de Chihuahua. Provincias Internas.

Temporalidades. Vol. 50, exp. 5, ff. 132-140. Bienes enajenados a los jesuitas. El presbitero Bachiller, Juan Francisco García, capellán de Hospital Militar de la Villa de Chihuahua solicita que en la capilla castrense de su cargo se celebren los novenarios de misas que antes estuvieron a los regulares convulsos.

Temporalidades. Exp. 7, ff. 278-293. Misión tarahumara en 1778. El comisionado Bustamante entrego alhajas, ornamentos al administrador del Hospital Real Militar, don Juan de Dios Calderón. De acuerdo al cédula de 7 de marzo de 1773 de bienes de temporalidades.

IV. Bienes de difuntos. C. 3406, exp. 036, 1 f. (1816). Chihuahua. El presbítero José Miguel Salas Valdez reconoce a Toribio Do Porto como tutor de los hijos del difunto cirujano Antonio Comadurán.

IV. Hospitales. C. O688, exp. 19, 6 ff. (1801). Regio Patronato Indiano. Antonio Comadurán. Licenciado en Ciencia y cirujano envía listas de medicamentos que hacen falta en el Real Hospital Militar, que se encuentra en la frontera de Sonora, Arizpe.

IV. Indiferente de guerra. C. 1391-003, 4 f. (1801-1802). Certificaciones otorgadas por Antonio Comadurán, Licenciado en Cirugía y cirujano de las tropas de Sonora. Sobre estado de salud de varios militares, a quienes recomendó baños de agua sulfúrea.

IV. Indiferente de guerra. C. 4428, exp. 028, f.1-1v. (1816). Certificado pedido por Toribio Do Porto sobre hallarse bajo su cuidado 
los hijos e hijas menores de Antonio Comadurán y Rovira, Cirujano del Hospital Militar de Chihuahua.

IV. Indiferente de guerra. C. 4545, exp. 047, 1f. (1802). Real tesorería de Arizpe. Ajuste de sueldo del cirujano Antonio Comadurán de enero a diciembre de 1802.

IV. Indiferente de guerra. C. 4949, exp. 031, 1f. (1796). 24 de mayo. Comisaría General de Guerra. Arizpe. Certificación que expidió Don Antonio Comadurán, licenciado en Cirugía de las tropas de Sonora; que el soldado Pedro Hernández estaba a sus cuidados y mando que se tomará baños sulfúricos de Aconchi.

IV. Indiferente de guerra. C. 4949, exp. 032 (1796). 9 de junio. José María Grijalba, caravinero del Presidio de Santa Cruz, sobre los gastos de asistencia del soldado Pérez, por recomendación del médico Comadurán.

IV. Intendencias. C. 4357, exp. 018, 12 f. (1794). Nicolás Hoz, administrador del hospital real militar de Arizpe, presenta al intendente de dicha provincia relación mensual de gastos en los enfermos y salarios de los empleados de dicho hospital.

IV. Protomedicato. C. 1224-006, 1-3, 8 f. (1794). 16 de abril. Informe sobre la recua que salió de esta capital, transportando medicina habilitada para el Hospital Militar de Arizpe.

Indiferente Virreinal. Protomedicato. C. 1241-018, 25 f. (1790). Informe del presidente del Real Tribunal de Protomedicato José Ignacio García, sobre el mal estado y mala clasificación de las medicinas del Real Hospital Militar de Chihuahua.

Indiferente Virreinal. Hospital Militar. C. 4545-047, 1 f. (1802). Real tesorería de Arizpe. Ajuste de sueldo del cirujano Antonio Comadurán de enero a diciembre de 1802. Cobra 678 pesos.

Indiferente Virreinal. Hospitales. C. 3983, exp. 009, 14 f. (1803). Hospital de la villa de Chihuahua. Propuesta enviada al virrey José de Iturrigaray, hecha por el maestro albañil Pedro Acuña y el carpintero Francisco Acosta, materiales y gastos que se necesitan invertir. Plano de la propuesta.

Indiferente virreinal. Hospitales. C. 6449, exp. 025, 2 f. (1795). 27 de abril. México. Escrito sobre expediente de erección del hospital 
real de Chihuahua, establecido en el colegio de exjesuitas de Chihuahua con aplicación de alhajas, imágenes y ornamentos.

\section{BIBLIOGRAFÍA}

Acevedo Tarazona, A. (2013). La prosopografía en la investigación histórica de Jorge Roa Martínez, Boyacá, 1891, Pereyra, 1966. Revista Historia y Memoria, (7).

Aguirre Beltrán, G. (1971). ¿Ha fracasado el indigenismo?, México: Secretaría de Educación Pública.

Aguirre Rojas, C. (2005). Los tres Méxicos en la historia de México. Contrahistorias, (4). Recuperado de: http://www.h-mexico. unam.mx.

Almada, F. R. (1955). Resumen de Historia del Estado de Chihuahua, México: Libros mexicanos.

(1968). Diccionario de historia, geografía y biografía chihuahuenses, Chihuahua: Universidad Autónoma de Chihuahua. (1990). Diccionario de historia, geografía y biografía sonorenses, Sonora: Instituto Sonorense de Cultura.

Almada Bay, I. (2000). Breve historia de Sonora. México: Fondo de Cultura Económica/El Colegio de México.

(1987). La medicina en el Virreinato, Historia mexicana, 36(3).

(1989). Pólvora, plomo y pinole. Algunas consideraciones sobre Sonora alrededor de 1821. XIII Simposio de Historia y Antropología. Simposio llevado a cabo en la Universidad de Sonora, Hermosillo.

Almada Bay, I., Medina Bustos, J. M., y Valle Borrero Silva, M. (2007). Hacia una nueva interpretación de régimen colonial en Sonora. Descubriendo a los indios y redimensionando a los misioneros,1681-1821. Región y Sociedad. Revista de El Colegio de Sonora, 19(número especial), 237-266.

Amaya González, L. (2001). Patriarcas del Papigochi. La descendencia, Monterrey: s.e. 
Archer, C. I. (1983). El ejército en el México borbónico, 1760-1810, México: Fondo de Cultura Económica.

Babini, J. (1971a). El saber en la historia. Buenos Aires: Centro Editor de América Latina.

Babini, J. (1971b). El siglo de las luces: ciencia y técnica, Buenos Aires: Centro Editor de América Latina.

Bernal, J. D. (1986). La ciencia en la historia, México: UNAM/ Editorial Nueva Imagen.

Bloch, M. (1979). Introducción a la historia, México: Fondo de Cultura Económica.

Brondo Whitt, E. (1952). Los patriarcas del Papigochi, Chihuahua: s.e. Ceballos Ramírez, M. (2009). El espacio mexicano. En Historia de México, México: FCE/SEP.

(2006). "La conformación del Noreste: larga duración, identidad y geopolítica”. Secuencia, Revista de Historia y Ciencias Sociales. No. 65. Mayo-agosto. Instituto Mora.

Cramaussel, C. (2017). Por allí pasó Rondé. Representaciones europeas de México a mediados del siglo XIX, México: El Colegio de Michoacán.

Chávez Marín, C. A. (2003). El Hospital Militar de Guadalajara y sus antecedentes, Zapopan, México: Amate.

Deeds, S. M. (1979). Las relaciones entre los jesuitas y los oficiales reales en Sinaloa y Sonora a mediados del XVIII. IV Simposio de Historia de Sonora. Simposio llevado a cabo en la Universidad de Sonora, IIH, Hermosillo.

Del Río Chávez, I. (2012). La aplicación regional de las reformas borbónicas en Nueva España. Sonora y Sinaloa 1768-1787. México: UNAM.

Domínguez Rascón, A. (2017). Autonomía, Insurgencia y oligarquía: Las provincias internas y la formación de los estados septentrionales. Historia mexicana, 66(3).

Escobar Ohmstede, Antonio y Teresa Rojas Rabiela, (Coords). (1992-1993). La presencia del indígena en la prensa capitalina del siglo XIX. Catálogo de noticias, México: CIESAS.

Flores y Troncoso, F. (1982). Historia de la medicina en México. Desde la época de los indios hasta el presente, México: IMSS. 
García de León, A. (2017). Misericordia. El destino trágico de una collera de apaches en la Nueva España, México: FCE.

García Martínez, B. (2008). Las regiones de México. Breviario geográfico e histórico, México: El Colegio de México.

Gerhard, P. (1996). La frontera norte de la Nueva España. México: UNAM.

Griffen, W. B. (1988). Apaches at war and peace. The Janos presidio. 1750-1858. Alburquerque, Nuevo México: University of New Mexico Press.

Gibson, C. (1977). España en América, México: Ediciones Grijalbo. Ginzburg, C. (2002) Microhistoria. Dos o tres cosas que se de ella. Ruptura (10-11).

Gutiérrez, E. O. (1993). El caso de la migración de Juan Puyol y las familias catalanas en Sonora (1777-1781). Memoria. XVI Simposio de Historia y Antropología de Sonora. Simposio llevado a cabo en la Universidad de Sonora, Instituto de Investigaciones, Hermosillo.

Housberger, B. (1998). La vida diaria de los jesuitas en las misiones del Noroeste novohispano. Memoria. XX Simposio de Historia y Antropología de Sonora. Simposio llevado a cabo en la Universidad de Sonora, IIH, Hermosillo.

Ibarra, A. C. (Coord.). (2012). La Independencia en el Septentrión de la Nueva España. Provincias internas e Intendencias norteñas, México: UNAM-IIH.

Jurado, F. (1781). Carta de fray Francisco Jurado, provincial del Santo Evangelio de México, dándole cuenta de sus actividades en España y Sonora. De Andalucía, España se traslada a Nueva España, donde llegó en 1771. En 1781 acompañó a Fray Antonio de los Reyes, Obispo de Sonora, para erigir la custodia de Sonora.

Katz, F. (2016). De Díaz a Madero. Orígenes y estallido de la Revolución Mexicana, México: Ediciones Era.

Lafora, N. (1939). Relación del viaje que hizo a los presidios internos situados en la frontera de América Septentrional. México, México: Pedro Robredo. 
Lister, F. C. y Lister, R. H. (1979). Chihuahua. Almacén de tempestades, México: Gobierno del Estado de Chihuahua.

Le Clézio, J. G. (2015). El sueño mexicano o el pensamiento interrumpido, México: FCE.

León García, R. y González Herrera, C. (2000). Civilizar o exterminar: Tarahumaras y apaches en Chihuahua. Siglo XIX, México: CIESAS-INI.

Levi, G. (1993). Sobre microhistoria. En Burke, P. (ed.), Formas de hacer historia (119-143), Madrid: Alianza Editorial.

León-Portilla, M. (2011). Independencia, Reforma, Revolución, ¿y los indios qué?, México: Consejo Nacional para la Cultura y la Artes/UNAM.

Márquez Terrazas, Z. (2010) Documentos para la historia de la Independencia de Chihuahua, Chihuahua, México: Universidad Autónoma de Chihuahua.

(2010). Ciudad de Chihuahua. Apuntes históricos, México: Grupo Cemento de Chihuahua.

(2011). Hidalgo. Documentos en Chihuahua, Chihuahua: Instituto Chihuahuense de la Cultura.

Martin, C. E. (2004). Gobierno y sociedad en el México Colonial. Chihuahua en el siglo XVIII, Chihuahua, México: Gobierno del Estado de Chihuahua.

Medina Bustos, J. M. y Padilla, E. (Coords.). (2015). Violencia interétnica en la frontera norte novohispana y mexicana. Siglos XVII-XIX, Hermosillo, Michoacán, Baja California: Colegio de Sonora/Colegio de Michoacán/Universidad Autónoma de Baja California.

(2012). La crisis de la monarquía hispánica en una zona de frontera: intendencia de Arizpe. 1808-1821. En Ibarra, A.C. (coord.), La independencia en el septentrión de la Nueva España: Provincias Internas e intendencias norteñas (217-248), México: UNAM.

Medina Bustos, J. M. y Padilla, E. (coordinadores). (2015). Indios, españoles y mestizos en zonas de frontera. Siglos XVIII-XIX. Colegio de Sonora. 
Mirafuentes Galván, J. L. (1998). El enemigo de las casas de adobe. Luis de Sáric y la rebelión de los pimas altos en 1751. Memoria. XXIII Simposio de Historia y Antropología de Sonora. Simposio llevado a cabo en la Universidad de Sonora, Instituto de Investigaciones, Hermosillo.

(1986). Elite y defensa en Sonora, siglo XVIII. Historias, (12), 67-79.

Morfi, J. A. (2003). Provincias Internas (Antología), México: UNAM. Muriel de la Torre, J. (1960). Hospitales de la Nueva España, México: Jus.

Navarro García, L. (1964). Don José de Gálvez y la comandancia general de las provincias internas de Nueva España. Sevilla: Escuela de Altos Estudios Hispanoamericanos de Sevilla.

Ocaranza, F. (2011), Historia de la Medicina en México, México: Consejo Nacional para la Cultura y las Artes.

O'Conor, H. (1952). Informe sobre el estado de las provincias internas del norte. 1771-1776. México: Cultura.

Officer, J. E. (1989). Hispanic Arizona, 1536-1856, Tucson: University of Arizona Press.

O'Gorman, E. (2007). Historia de las divisiones territoriales de México, México: Porrúa.

Orozco, V. (2011). Tres preguntas del doctor Friedrich Katz sobre la historia del estado de Chihuahua. En J. Garciadiego y Emilio K. (Comps.), Revolución y exilio de México. Homenaje a Friedrich Katz (315-326), México: Ediciones Era/El Colegio de México.

Ortega Noriega, S. y del Río, I. (Coords). (2010). Tres siglos de historia sonorense. 1530-1830, México: UNAM.

Ortelli Pellizari, S. (2007). Trama de una guerra conveniente: Nueva Vizcaya y la sombra de los apaches, 1748-1790, México: El Colegio de México.

Radding Murrieta, C. (1992). Población, tierra y la persistencia de la comunidad en la provincia de Sonora. 1750-1868. HMex, XLI(4), 551-557. 
(2015). Pueblos de frontera: coloniaje, grupos étnicos y espacios ecológicos en el Noroeste de México. 1700-1850, México: El Colegio de Sonora/Instituto Sonorense de Cultura.

Ramírez Ortega, V. (2010). El Real Colegio de Cirugía de la Nueva España, México: UNAM-IIS.

Ramos, R. (1778). Descripción hecha en el año de 1778 por el padre fray Agustín de Morfi sobre Arizpe, Sonora, capital que fue de las provincias internas.

Reyes, A. (2012). La "X" en la frente. Textos sobre México, México: UNAM.

Riesgo, J. M. et al. (1822). Memoria sobre las proporciones naturales de las provincias internas occidentales, causas de que han provenido los atrasos, providencias internas tomadas con el fin de lograr su remedio y las que ahora se consideran oportunas para mejorar su estado. Formada por Juan Miguel Riesgo, México, José María Ramos Palomera.

Río, I. (1996). De la pertinencia del enfoque regional en la investigación histórica sobre México. En Río, I. Estudios históricos sobre Sonora y Sinaloa (siglos XV-XVIII), La Paz, Baja, México: SEP/UABC.

(2007). El Noroeste del México Colonial. Estudio Histórico sobre Sonora, Sinaloa y Baja California, México: UNAM/IIH.

(2012). La aplicación regional de las reformas borbónicas en Nueva España. Sonora y Sinaloa, 1768-1787, México: UNAM/IIH. Rivera Villalón, P. (1946). Diario y derrotero de lo caminado, visto y observado en la visita que hizo a los presidios internos, situados en la frontera de la América Septentrional el Brigadier Pedro Rivera Villalón, México: Sedena.

Rodríguez-Sala, M. L. (2005). Los Cirujanos del Ejército en la Nueva España. 1713-1820, México: UNAM-IIS.

(2012). Los cirujanos privados en Nueva España México, México: UNAM-IIS.

Rubial García, A. (2004). (coord.), Historia de la vida cotidiana en México, México: El Colegio de México/FCE.

(2014). El virreinato de Nueva España en el siglo XVIII. En Wobeser, G. (coord.), Historia de México (183-216), México, FCE. 
Sáenz de la Calzada, C. (1971). La Geografía Médica en México a través de la historia, México: Editorial Pax-México.

Salado Alvarado, V. (2017). México en tierra yanqui, México: UNAM.

Sandoval, F. B. (1948). El correo en las provincias internas. 1729, México: Junta Mexicana de Investigaciones Históricas.

Tonella Trelles, M. (2000). Las mujeres en los testamentos registrados en los distritos de Hermosillo y Arizpe, Sonora. 1786-1861. (Tesis de Grado). Universidad de Sonora, Departamento de Historia y Antropología, Hermosillo.

Trueba Lara, J. L. (1993). La locura del visitador Gálvez. Medicina y poder en el México Borbónico. XVIII Simposio de Historia y Antropología. Simposio llevado a cabo en la Universidad de Sonora, Hermosillo.

Válery, P. (1940). Discurso a los cirujanos. Aforismos, México: Nueva Cultura.

Van Young, E. (1991). Haciendo historia regional. Consideraciones metodológicas y teóricas. En Pérez Herrero, P. (Comp.), Región e Historia en México. 1700-1850. Método de análisis regional (99-122), México: Instituto Mora, UAM.

Vázquez González, R. (2017). De la cirugía a la medicina quirúrgica en Puebla, 1778-1832, Puebla, México: BUAP.

Velasco Ávila, Cuauhtémoc. (2015). Pacificar o negociar: LoS acuerdos de paz con apaches y comanches en Provincias Internas. 1784-1792. México, Instituto Nacional de Antropología e Historia.

Velázquez, M. (1952). La Frontera Norte y la experiencia colonial, México: Secretaría de Relaciones Exteriores.

(1974). Establecimiento y pérdida del septentrión de Nueva España, México: El Colegio de México.

(1977). La comandancia general de provincias internas. Historia Mexicana, 27(2), 163-176.

(1979). Tres estudios sobre las Provincias Internas, México: El Colegio de México.

Vidargas del Moral, J. D. (1993). El cabildo intermitente de Arizpe y sus pretensiones y proposiciones en 1813. XVIII Simposio de 
Historia y Antropología. Simposio llevado a cabo en la Universidad de Sonora, Hermosillo.

(2011). Breve historia de Cataluña, Barcelona: Universitat Autònoma de Barcelona.

Weber, D. S. (2000). La frontera española en América del Norte, México: Fondo de Cultura Económica. 